\title{
Kvalita života osob s amputací dolní končetiny a dotazník TAPES-R
}

\section{Quality of Life of People with Lower Limb Amputation and TAPES-R Questionnaire}

\author{
Hana Zakouřilová ${ }^{1}$, Univerzita Karlova, Pedagogická fakulta, Praha
}

\begin{abstract}
Abstrakt
Článek se zabývá kvalitou života osob po amputaci končetiny zjištovanou pomocí dotazníku TAPES-R. Otázky v dotazníku se zaměřují na čtyři oblasti - psychosociální přizpůsobení, omezení činnosti, spokojenost s protézou, zkoumání fantomové bolesti končetin, zbytkové bolesti končetin a dalších zdravotních stavů nesouvisejících s amputací. V srpnu 2021 proběhl on-line formou předvýzkum za použití české verze dotazníku, kterého se zúčastnilo dvacet jedna respondentů. Skupina byla různorodá, jak z pohledu věku, tak i délky doby od amputace, a i typu amputace.
\end{abstract}

\section{Klíčová slova}

kvalita života, osoby po amputaci, TAPES-R, protéza

\begin{abstract}
The article deals with the quality of life of persons after limb amputation determined using the TAPES-R questionnaire. The questions in the questionnaire focus on four areas - psychosocial adjustment, activity limitation, satisfaction with the prosthesis, examination of phantom limb pain, residual limb pain and other non-amputation-related medical conditions. In August 2021, a preliminary survey was conducted online using the Czech version of the questionnaire, which was attended by twenty-one respondents. The group was diverse, both in terms of age and length of time since amputation, and the type of amputation.
\end{abstract}

\section{Keywords}

quality of life, amputation, TAPES-R, prosthetic

\section{Úvod}

Tělesné postižení představuje znevýhodnění dané nejen určitým omezením, ale i mírou jeho subjektivního zvládnutí a sociální pozice jedince. Z psychologického hlediska platí, že jakékoli postižení se neprojeví jen poruchou funkcí jednoho orgánového systému, ale ovlivňuje rozvoj celé osobnosti postiženého jedince a podílí se na vytvoření specifické sociální situace spoluurčující jeho společenské postavení. (Vágnerová,2008, s. 161) Kvalita života je pojem, který je velmi těžce uchopitelný, definovatelný a lze nahlížet z mnoha stran.

V současné době existuje několik standardizovaných dotazníků měřících kvalitu života související se zdravím, například dotazník WHOQOL-100, WHOQOL-BREF, SF-36 (Short Form 36 - Health Subject Questionnaire). Některé z dotazníků jsou v české verzi upraveny pro specifickou populaci - WHOQOL-OLD. Specializovaný dotazník zjištujující kvalitu života pro osoby po amputaci končetin/y není v České republice volně k dispozici. V zahraničí je jeden ze speciálně vytvořených dotazníků pro osoby po amputaci dotazník The Trinity Amputation and Prosthesis Experience Scales - Revised (TAPES-R).

Tento článek se bude zabývat převodem tohoto dotazníku do českého jazyka a jeho ověření. Cílem je získat první ucelenější data z většího souboru respondentů po amputaci a následně s těmito daty pracovat s dopadem na zlepšení kvality života osob po amputaci.

1 Kontaktní osoba: hzakourilova@gmail.com 


\section{Současný stav poznání}

Pojem „kvalita života“ poprvé zmínil Pigou v roce 1920 v práci zabývající se ekonomií a sociálním zabezpečením. Nesetkal se však s ohlasem a pojem byl objeven až po 2. světové válce. V té době Světová zdravotnická organizace rozšířila definici zdraví, kdy zahrnovala fyzickou, duševní a sociální pohodu. V 60. letech 20. století vznikala různá sociální hnutí a politické iniciativy zabývající se nerovností (Mühlpachr, Vad'urová 2006, s.85) V Evropě se pojem kvality života objevuje v programu nevládní organizace, založené ve Švýcarsku, tzv. Římského klubu. Jednou z hlavních aktivit bylo programové zvyšování životní úrovně lidí a jejich kvality života. Prohlášení vyvolalo řadu reakcí. V 70. letech vyšlo množství publikací, které se zabývaly definováním pojmu kvality života. (Halečka, 2001, s. 65-66)

V současné době Mareš definuje tři problémy tohoto termínu - oborová různost, sám pojem jako takový (sice navozuje dojem komplexního ukazatele, ale jedná se o výběr selektivní, nekompletní zachycení události), a v neposlední řadě je nutné jemněji rozčlenit, odlišit jednotlivé aspekty pojmu. (Mareš, 2006, s. 11) Heřmanová zase konstatuje, že obtížná uchopitelnost vybraného tématu se přímo odvíjí od komplexnosti a složitosti lidského života jako takového, tj. od skutečnosti, že život jedince je utvářen de facto nekonečným množstvím koexistujících vnitřních a vnějších faktorů, řadou nejrůznějších interakcí a činností v překrývajících se zájmových oblastech a v překrývajících se sociálních skupinách, v neposlední řadě pak může být život jedince utvářen i řadou náhod (Heřmanová, 2012). Vymětal přistupuje ke konceptu kvality života ze dvou hledisek - objektivního (materiální zabezpečení, sociální podmínky života, sociální status) a subjektivního (jedincovo vnímání svého postavení ve společnosti v kontextu jeho kultury a hodnotového systému). (Vymětal, 2003, s. 198-199)

\section{Amputace}

Amputace je definována jako oddělení periferní části těla od organizmu. Jejím důsledkem je funkční nebo kosmetická změna. Maggie k definici ještě přidává, že se jedná o odstranění části nebo celé končetiny či jiné části těla (Maggie, 2007). V tomto článku se zaměřujeme na osoby po amputaci v oblasti dolní končetiny. Ty se dělí podle lokalizace místa amputace - amputace v oblasti nohy, tibiální, exartikulace v kolenním kloubu, femorální amputace, exartikulace v kyčelním kloubu, hemipelvektomie, hemikorporektomie (Ottobock, 2021). I když jsou amputace rozděleny dle místa, žádná amputace není identická. Z tohoto důvodu se vyhotovují protetické pomůcky individuálně „na míru“ každému člověku po amputaci, a to nejen z důvodu rozdílu zbylé končetiny, ale také z důvodu stupně aktivity. Dle toho se volí jednotlivé díly, ze kterých jsou protézy složeny. Může se jednat o zcela jednoduchou protézu složenou ze základních komponentů, ale také může být vyrobena protéza speciálně určená na sportovní aktivity - běh, lyže atp.

Mezi důvody provedení amputace se řadí autonehody, nehody na motorce apod.; pracovní úrazy; válečná poranění; nádorová onemocnění; infekce nereagující na konzervativní léčbu; onemocnění cév - spojeno např. s Diabetes mellitus; anomálie končetin, případně afunkční část končetiny. V roce 2019 bylo realizováno v oblasti horní končetiny 3214 amputací, v oblasti dolní končetiny 6106 amputací a dalších 2025 není identifikováno. Nejvíce amputací bylo provedeno ve věkové kategorii 70-80 let. V letech 20102019 bylo provedeno 557 amputací u dětí do 10 let. V období 2010-2019 bylo celkově realizováno 81962 amputací u mužů (z toho 21042 v oblasti horní končetiny, 42929 v oblasti dolní končetiny, 17991 neurčených) a 28050 u žen (z toho 6638 v oblasti horní končetiny, 12592 v oblasti dolní končetiny a 8820 neurčitých). ${ }^{2}$

\section{Kvalita života osob po amputaci}

V zahraničních výzkumech bylo (Hagberg 2006) popsáno, že kvalitu života osob po amputaci ovlivňuje zvýšené pocení v oblasti objímky (uchycení protézy), problémy s kůží v oblasti pahýlu. Dále také kvalitu života ovlivňuje nepohodlnost při sezení, zmenšený rozsah pohybu v oblasti kyčelního kloubu (pohyb omezuje objímka protézy). V další studii se zaměřením na rychlost a symetrii chůze u osob po amputaci konstatovali, že na kvalitu života má vliv bolest v oblasti „zbylé celé“ končetiny, která je více zatěžována a také bolesti v oblasti zad (Nolan, 2003). 


\section{Metoda}

Měření kvality života u osob po amputaci je možné pomocí dotazníku The Trinity Amputation and Prosthesis Experience Scales - Revised (TAPES-R)³, který vznikl v roce 2010 v Dublinu v Irsku. Dotazník je multidimenzionální nástroj určený k sebetestování osob po amputaci.

Dotazník se skládá ze čtyř částí:

1. Psychosociální přizpůsobení (obecné přizpůsobení, sociální přizpůsobení a přizpůsobení omezujícím dílčím měřítkům);

2. Omezení činnosti;

3. Spokojenost s protézou (funkční a estetická);

4. Zkoumání fantomové bolesti končetin, zbytkové bolesti končetin a dalších zdravotních stavů nesouvisejících s amputací.

Tento dotazník není primárně určen pouze pro osoby po amputaci dolní končetiny, ale jeho využití je možné i osob po amputaci v oblasti horní končetiny.

V současné době (tedy k září 2021) existuje několik jazykových mutací - v anglickém jazyce (původní dotazník), francouzském jazyce ${ }^{4}$ (TAPES-R-F), v brazilské portugalštině ${ }^{5}$, turečtině ${ }^{6}$, arabštině ${ }^{7}$, perštině ${ }^{8}$.

\section{TAPES-R v České republice}

Aktuálně byl dotazník TAPES-R přeložen a prošel zpětným překladem - tedy zpět z českého jazyka do jazyka anglického. Během srpna 2021 proběhl předvýzkum, kdy byly osloveny osoby po amputaci končetin/y přes sociální sítě (konkrétně Facebookovou skupinu - Amputáři). Také byly osloveny konkrétní osoby po amputaci, na které byly k dispozici přímé kontakty z dřívější spolupráce. Všichni respondenti vyplňovaly on-line formu dotazníku. Respondenti mimo základních otázek zjištujujicí věk, pohlaví, důvod amputace, dobu od provedení amputace, odpovídaly na otázky uvedené níže.

\section{Otázky v části 1 - Psychosociální přizpůsobení}

1. Přizpůsobil jsem se protéze.

2. S postupem času více přijímám svoji protézu.

3. Mám pocit, že jsem se s tímto traumatem ve svém životě úspěšně vypořádal.

4. I když mám protézu, můj život je naplňující.

5. Zvykl jsem si na nošení protézy.

6. Neřeším, jestli se někdo dívá na protézu.

7. Snadno se mi o protéze mluví.

8. Nevadí mi, že se lidé na protézu ptají.

9. Snadno se mi mluví o ztrátě končetiny.

\section{Základní psychometrická data k dotazníku TAPES-R jsou publikována zde:}

Gallagher, P., Franchignoni, F., Giordano, A., \& MacLachlan, M. (2010). Trinity amputation and prosthesis experience scales: A psychometric assessment using classical test theory and rasch analysis. American Journal of Physical Medicine and Rehabilitation, 89(6), 487-496. https://doi.org/10.1097/PHM.0b013e3181dd8cf1

4 I. Loiret, P. Vuistinier, J. Paysant, Y. Arlettaz, M. Assal, O. Borens, L. Huchon, N. Martinet, A. Vouilloz, F. Luthi (2015) Cross-cultural adaptation, reliability, internal consistency and validation of the Trinity Amputation and Prosthetic Experience Scales-Revised (TAPES-R) for French speaking patients with lower limb amputation. Annals of Physical and Rehabilitation Medicine, Volume 58, Supplement 1, Page e127, https://doi.org/10.1016/j.rehab.2015.07.304.

5 Pires, G. K. W., da Silva, F. C., Luza, L. P., Gutierres Filho, P. J. B., Deans, S., \& da Silva, R. (2020). Semantic equivalence in Brazilian Portuguese translation of the Trinity Amputation and Prosthesis Experience Scales-Revised. Prosthetics and Orthotics International, 44(2), 66-72. https://doi.org/10.1177/0309364620906668

6 Topuz S, Ülger Ö, Yakut Y, Gül Șener F. Reliability and construct validity of the Turkish version of the Trinity Amputation and Prosthetic Experience Scales (TAPES) in lower limb amputees. Prosthet Orthot Int. 2011 Jun;35(2):201-6. doi: 10.1177/0309364611407678. PMID: 21697202.

7 Massarweh, R. and Sobuh, M.M.D., 2019. The Arabic Version of Trinity Amputation and Prosthetic Experience Scale - Revised (TAPES-R) for Lower Limb Amputees: Reliability and Validity. Disability, CBR \& Inclusive Development, 30(1), pp.44-56. DOI: http://doi.org/10.5463/dcid.v30i1.718

8 Mazaheri M, Fardipour S, Salavati M, Hadadi M, Negahban H, Bahramizadeh M, Khosrozadeh F. The Persian version of Trinity Amputation and Prosthetics Experience Scale: translation, factor structure, reliability and validity. Disabil Rehabil. 2011;33(19-20):1737-45. doi: 10.3109/09638288.2010.544838. Epub 2010 Dec 24. PMID: 21184630. 
10. Je mi jedno, že si někdo všimne, že pokulhávám.

11. Protéza narušuje schopnost vykonávat moji práci.

12. Protéza mě činí závislejším na ostatních více, než bych chtěl.

13. Protéza mě limituje v druhu práce, kterou mohu dělat.

14. Být po amputaci znamená, že nemohu dělat, co bych chtěl.

15. Mít protézu omezuje množství práce, kterou mohu udělat.

\section{Otázky v části 2 - Omezení činnosti}

A. Energeticky náročné aktivity, jako je běh, zvedání těžkých předmětů, účast na namáhavém sportu.

B. Zdolání několika poschodí

C. Běh na autobus/vlak

D. Sport a rekreace

E. Zdolání jednoho poschodí

F. Chůze delší než $1,5 \mathrm{~km}$.

G. Chůze delš́í než $500 \mathrm{~m}$

H. Chůze delší než $100 \mathrm{~m}$

I. Koníčky

J. Chození do zaměstnání

\section{Otázky v části 3 - Spokojenost s protézou}

I. Barva

II. Tvar

III. Vzhled

IV. Váha

V. Účelnost/užitečnost

VI. Spolehlivost

VII. Uchycení protézy

VIII. Pohodlí

\section{Otázky v části 4 - Zkoumání fantomové bolesti končetin, zbytkové bolesti končetin a dalších zdra-} votních stavů nesouvisejících s amputací

1. Jak celkově hodnotíte své zdraví?

2. Jak celkově hodnotíte své fyzické schopnosti?

3. Máte zkušenost s bolestí ve zbývající části Vaší končetiny (pahýlu).

a. Jak často jste během posledního týdne cítil bolest v pahýlu?

b. Jak dlouho v průměru tato bolestivá epizoda trvala?

c. Prosím uved'te průměrnou míru bolesti v pahýlu za poslední týden na níže uvedené stupnici.

d. Jak moc Vám tato bolest bránila v běžném životě (např. práce, sociální a rodinné aktivity) během posledního týdne?

4. Máte zkušenost s Fantomovými bolestmi (bolest v části končetiny, která byla amputována)?

a. Během posledního týdne, jak často jste zažil Fantomovou bolest?

b. Jak dlouho v průměru tato bolest trvala?

c. Prosím, uved'te průměrnou intenzitu Fantomových bolestí za poslední týden na níže uvedené stupnici.

d. Jak moc Vám tato bolest bránila v běžném životě (nap̌̌. práce, sociální a rodinné aktivity) během posledního týdne?

5. Máte zkušenosti s jakýmikoliv dalšími problémy kromě bolesti v pahýlu a Fantomových bolestech?

a. Prosím, upřesněte s jakými problémy máte zkušenost.

b. Jak často jste během posledního týdne trpěl těmi to zdravotními problémy?

c. Jak dlouho průměrně tento problém trval?

d. Prosím, uved'te průměrnou intenzitu bolesti způsobené těmito zdravotními problémy za poslední týden na níže uvedené stupnici: 
e. Jak moc Vám tyto zdravotní problémy bránily v běžném životě (nap̌̌. práce, sociální a rodinné aktivity) během posledního týdne?

6. Zažíváte nějakou jinou bolest, kterou jste ještě nezmínil výše?

a. Jestliže jiste v předchozí otázce odpověděl Ano, prosím upřesněte, o jakou bolest se jedná.

\section{Výsledky}

Pro tento článek budou využita data získaná v období od 24. 8. do 7. 9. 2021. Za tuto dobu dotazník vyplnilo 21 osob po amputaci, z toho 8 žen a 13 mužů. Průměrná doba vyplnění činila 12 minut. Z dvaceti jedna osob mají amputaci pod kolenem jedenáct osob, nad kolenem osm osob, jedna v koleni, jedna uvedla jiné a jedna osoba je po amputaci nad loktem. Věkové rozmezí od 19 do 67 let, s průměrem 52 let.

Důvodem amputace byla nejčastěji nehoda, a to v devíti případech, následně „jiné“ v sedmi případech (meningitida, nehybná část končetiny po nehodě, genetická vada, nespecifikovaný „bacil“), dále diabetes ve třech případech, rakovina ve dvou, periferní vaskulární porucha v jednom případu.

\section{Otázky zaměřené na psychosociální přizpůsobení amputaci}

V této části se odpovídá na patnáct otázek. Respondent vyjadřuje svůj souhlas/nesouhlas s daným výrokem (zcela nesouhlasím, nesouhlasím, souhlasím, zcela souhlasím, nevím). Jednotlivé odpovědi na výroky byly sumarizovány a následně bude uveden popis výsledků. Sedmnáct respondentů se protéze přizpůsobilo a stejný počet s postupem času přijímá svoji protézu více. Nejedná se však o ty samé respondenty. Stejný počet vnímá, že se s traumatem vypořádali, jeden neví. Naplněnost svého života kladně popisuje šestnáct osob. Již méně, patnáct respondentů, si na nošení protézy zvyklo. Tuto skutečnost ale neovlivňuje délka uživání protézy. Třem respondentkám vadí, že se na protézu někdo dívá. Všem se ale o protéze snadno mluví. Jedné respondentce vadí, že se ji lidé na protézu ptají. Třem respondentům se nemluví o ztrátě končetiny snadno. Zajímavé je, že se jedná o osoby, které jsou po amputaci již delší dobu (30 a 56 let). Opět jen dvěma respondentům vadí, že si někdo všimne, že pokulhávají. Necelé dvě třetiny respondentů se shodují, že protéza narušuje schopnost vykonávat jejich práci. Pět respondentů se cítí závislejší na okolí více, než by chtěli. Limit v druhu práce vnímají všichni respondenti po amputaci nad kolenem. Osoby s amputací pod kolenem - šest jich nesouhlasí a pět se cítí limitováno. Dvanáct respondentů vnímají omezení v tom, co by chtěli dělat. Ještě o dva více vnímají omezení v množství práce.

\section{Otázky zaměřené na limity v aktivitách běžného dne}

Respondenti se vyjadřují na škále - ano, hodně limitován; ano, jen málo limitován; ne, nejsem limitován. V otázce zaměřené na energeticky náročné aktivity (běh, namáhavý sport) se necítí limitována osoba po amputaci nad loktem a jedna pod kolenem. Osm respondentů se necítí limitováno při zdolání několika poschodí. V běhu na autobus kromě osoby po amputaci nad loktem pocitují omezení všichni zbylí respondenti. Ve sportovně rekreačních aktivitách má pocit limitu osmnáct respondentů. Zdolání jednoho podlaží je limitující pro tři respondenty. Chůze na více než $1,5 \mathrm{~km}$ je náročný pro deset osob po amputaci, na 500m pro osm a chůze na delší než 100m limituje dva respondenty. V koníčcích vnímá limit čtrnáct osob. V oblasti zaměstnání osm osob není limitováno, pět neodpovědělo.

\section{Otázky zaměřené na spokojenost s protetickou náhradou}

Otázky jsou škálovány na velmi spokojen, spokojen, nespokojen. Dotazují se na barvu, vzhled, váhu, spolehlivost, uchycení, pohodlí. Lze konstatovat, že dvě třetiny respondentů se cítí velmi spokojeny či spokojeny napříč oblastmi. Největší nespokojenost je pocitóována v oblasti vzhledu, váhy, pohodlí (po pěti respondentech), nespokojeni se spolehlivostí jsou čtyři respondenti a tři jsou nespokojeni s uchycením.

Doba užívání protetické náhrady se u čtrnácti osob pohybuje v časovém rozmezí 10-16h denně, pět respondentů naopak uživá protetickou náhradu méně než 5 hodin denně. Nejméně je užívána na 0,5 hodiny denně, naopak nejvíce na 16 hodin denně.

\section{Otázky zaměřené na zdraví a bolest}

V těchto otázkách respondenti vybírali z možnosti odpovědí - velmi špatně, špatně, přiměřeně, dobře, velmi dobře. Otázky jsou členěny na zkušenosti s bolestí ve zbytkové části končetiny, zvlášt' je dotazováno 
na tzv. Fantomovy bolesti. Poslední část otázek mapuje další problémy v oblasti zdraví kromě bolestí v pahýlu a Fantomových bolestí.

Celkově své zdraví hodnotily v jedenácti případech jako velmi dobře, dobře. Přiměřeně se cítilo osm osob. Špatně a velmi špatně se cítily tři osoby. Své fyzické schopnosti označilo za přiměřené devět respondentů, dobře či velmi dobře deset respondentů. Špatně a velmi špatně tři respondenti. Dvě osoby vnímají své celkové zdraví i fyzické schopnosti jako špatné či velmi špatné.

Zkušenost s bolestí ve zbývající části končetiny má14 osob. V posledním týdnu tuto bolest někdo cítil denně, jiný respondent „při změně počasí“. Doba bolesti se pohybuje v rozmezí od několika málo sekund až po brnění po celý den. Jako nesnesitelnou či strašnou tuto bolest označují dva respondenti. Pro šest respondentů jsou tyto bolesti nepř́ijemné. Trochu či mírně bránila tato bolest v běžné činnosti devíti respondentům. Dvěma bránila hodně.

Zkušenost s Fantomovou bolestí má 18 respondentů. V posledním týdnu se vyskytla u čtrnácti z nich. Doba se pohybuje od několika málo sekund po hodiny (celou noc). Nesnesitelné či strašné byly pro tři osoby. V běžném životě limitovala čtyři respondenty.

S dalším bolesti má zkušenost sedm respondentů, a to především v oblasti zad, poškození kůže, bolesti kloubů z přetěžování zbylé končetiny a paží. Tyto problémy řeší většinou stále. Trpí jimi dlouhodobě. Vnímají je převážně jako nepř́ijemné a trochu je limitují v běžném životě. Dva respondenti ale tyto bolesti vnímají jako strašné či znepokojující a hodně či docela dost je limitují v běžném životě.

\section{Diskuse}

Dotazník byl v České republice použit touto formou poprvé. Omezen byl výběr respondentů vzhledem k užívání sociální sítě a ochotě dotazník vyplnit. V některých položkách by chtělo více upřesnit jednotky, např. v položkách s dotazem na délku trvání bolesti. Zároveň toto upřesnění by pro některé respondenty mohlo být svazující, jelikož se v odpovědích velmi lišily, tak jako se liší samotná bolest. V dotazníku není možné rozlišit kombinaci dvou amputací, např. amputace obou dolních končetin či kombinace horní a dolní končetiny. Toto rozlišení by mohlo být nápomocné v dalším vyhodnocování získaných dat.

Z výše pospaných výsledků by se dalo vyvodit, že ne vždy je rozhodující doba od amputace. Tedy že čím delší doba od amputace uplynula, tím lépe je osoba po amputaci s touto změnou sžitá.

Některé položky ovlivňuje pohlaví (týkající se pozornosti na protézu). Zajímavým zjištěním je různorodost osob, které dotazník vyplnily. Různorodost je to jak z pohledu věku, tak i z pohledu délky užívání protetické náhrady. Velmi výrazně je omezen pohyb na delší vzdálenost než 1,5km bez ohledu na místo amputace (pod kolenem, nad kolenem).

V otázkách zaměřených na protetickou náhradu bylo překvapivé, že většině respondentů vyhovuje. Tento fakt mohl ovlivnit i samotný výběr respondentů, jelikož to jsou lidé aktivní, v kontaktu s jinými osobami po amputaci, dohledávající si informace a diskutující na sociální síti. Sami tak mohou klást dotazy ohledně funkčnosti protetické náhrady či samotného uchycení.

Položky zabývající se bolestí poukazují na velkou zkušenost respondentů s bolestí jak krátkodobou, tak i bolestí trvající několik hodin. Není ale zřejmé, zda a jak odlišují pojmy bolest a Fantomovy bolesti. Zkušenost s bolestí ve zbytkové části končetiny uvedlo méně respondentů než těch, co mají zkušenost s Fantomovými bolestmi. Hranice mezi bolestí a Fantomovou bolestí je nejspíše pro každého jiná nebo je také možné, že respondentům nebyl nijak vysvětlen či popsán rozdíl.

Pro získání většího vzorku respondentů a více dat by bylo zapotřebí se spojit s více osobami po amputaci. Kontaktovat zdravotnická zařízení, protetická pracoviště, zájmové organizace, asociace. K tomu by bylo potřeba dotazník nemít k dispozici pouze v on-line formě, ale i jeho grafické zpracování ve formě tištěné. Tištěná varianta dotazníku je náročnější na spolupráci odborné veřejnosti, ochotě pracovníků se do výzkumu zapojit a také na samotnou distribuci mezi osoby po amputaci a následné zpravování.

\section{Závěr}

Tento článek se věnoval dotazníku The Trinity Amputation and Prosthesis Experience Scales - Revised (TAPES-R) a jeho českému překladu. Dotazník se zaměřuje na čtyři oblasti v životě osob po amputaci. V České republice není k dispozici ucelený dotazník tohoto typu, který by byl využíán mezioborově.

Data z předvýzkumu ukazují na různorodost skupiny osob po amputaci. Zároveň však poukazují na určité spojitosti nezávisle na věku, uplynutí doby od amputace, pohlaví, typ amputace. Rozdíly jsou v aktivitách 
patrné mezi osobami po amputaci dolní končetiny a horní končetiny. V oblasti bolesti ale významné rozdíly nejsou.

Jistě by bylo zajímavé a přínosné získání dat od většího počtu respondentů. Data by mohla být využita např́č obory - ve speciální pedagogice, rehabilitaci, psychologii, medicíně, v protetické péči, urbanistice, robotice atd.

\section{Literatura}

Halečka, T. (2002) Kvalita života a jej ekologicko-enviromentální rozmer. In Kvalita života a ludská práva v kontextech sociálnej práce a vzdelavanie dospelých. Prešov. ISBN 80-8068-088, s. 65-66

Hagberg, K. (2006). Transfemoral Amputation, Quality of Life and Prosthetic Function. 2006. Göteborg, Sweden: Västra Frölunda. DOI https://gupea.ub.gu.se/bitstream/2077/726/1/GUPEA.pdf

Heřmanová, E. (2012). Kvalita života a její modely v současném sociálním výzkumu. Sociológia 4. 2012. 478-496. Mareš, J. a kol. (2006) Kvalita života u dětí a dospívajících I. Vydalo MSD, spol. s r.o. Brno. ISBN 80-86633-65-9

Mühlpachr, P., Vadurová, H. (2006) Vymezení, dimenze a měření kvality života. In Kapitoly ze speciální pedagogiky. Brno: Paido. ISBN 80-7315-120-0

Maggie, DJ. (2007). Orthopaedic physical assessment. 5th ed. Saunders Elsevier: Missouri.

Massarweh, R. and Sobuh, M.M.D., 2019. The Arabic Version of Trinity Amputation and Prosthetic Experience Scale - Revised (TAPES-R) for Lower Limb Amputees: Reliability and Validity. Disability, CBR \& Inclusive Development, 30(1), pp.44-56. D0I: http://doi.org/10.5463/dcid.v30i1.718

Mazaheri M, Fardipour S, Salavati M, Hadadi M, Negahban H, Bahramizadeh M, Khosrozadeh F. The Persian version of Trinity Amputation and Prosthetics Experience Scale: translation, factor structure, reliability and validity. Disabil Rehabil. 2011;33(19-20):1737-45. doi: 10.3109/09638288.2010.544838. Epub 2010 Dec 24. PMID: 21184630.

Nolan, L., Wit, A., Dudziñski, K., Lees, A., Lake, M., \& Wychowañski, M. (2003). Adjustments in gait symmetry with walking speed in trans-femoral and trans-tibial amputees. Gait \& Posture, 17(2), 142-151. DOI https://doi.org/10.1016/S0966-6362(02)00066-8

Loiret, I., Vuistinier, P., Paysant, J., Arlettaz, Y., Assal, M., Borens, O., Huchon, L., Martinet, N., Vouilloz, A., Luthi, F. (2015) Cross-cultural adaptation, reliability, internal consistency and validation of the Trinity Amputation and Prosthetic Experience Scales-Revised (TAPES-R) for French speaking patients with lower limb amputation. Annals of Physical and Rehabilitation Medicine, Volume 58, Supplement 1, Page e127, https://doi.org/10.1016/j.rehab.2015.07.304.

Pires, G. K. W., da Silva, F. C., Luza, L. P., Gutierres Filho, P. J. B., Deans, S., \& da Silva, R. (2020). Semantic equivalence in Brazilian Portuguese translation of the Trinity Amputation and Prosthesis Experience Scales-Revised. Prosthetics and Orthotics International, 44(2), 66-72. https://doi. org/10.1177/0309364620906668

Topuz S, Ülger Ö, Yakut Y, Gül Șener F. Reliability and construct validity of the Turkish version of the Trinity Amputation and Prosthetic Experience Scales (TAPES) in lower limb amputees. Prosthet Orthot Int. 2011 Jun;35(2):201-6. doi: 10.1177/0309364611407678. PMID: 21697202.

Vágnerová, M. (2008) Psychopatologie pro pomáhající profese. Portál. ISBN 978-80-7367-414-4

Vymětal, J. (2003) Úvod do psychoterapie. Praha. Grada. ISBN 80-247-0253-3

Úroveň amputace. (nd) Otto Bock . Retrived June 26, 2021 from https://www.ottobock.cz/protetika/informace-pro-amputovane/uroven-amputace/

\section{Informace o autorech}

\section{Mgr. Hana Zakouřilová, MBA}

Speciální pedagožka, psychoterapeutka, studentka 2. ročníku doktorského studia na Pedagogické fakultě Univerzity Karlovy v Praze. Pracuje v PPP Ústí nad Orlicí. Psychoterapeutickou praxi má v Kostelci nad Orlicí. Kontaktní údaje:

Telefon: +420604449406

Email: hzakourilova@mail.com

URL: www.hzakourilova.proweb.cz 